\title{
Effect of Dichlorvos on Selected Metabolites, Enzymes and Electrolytes in Some Parts of Oryctolagus Cuniculus (New Zealand Rabbits)
}

\author{
Iniobong R. Inyang ${ }^{1}$, Ibarakumo Isaac Gad ${ }^{1}$, Sylvester C. Izah ${ }^{2 *}$ \\ ${ }^{I}$ Ecotoxicological Research Unit, Department of Biological Science, Niger Delta University, Wilberforce Island, \\ Bayelsa State, Nigeria \\ ${ }^{2}$ Department of Biological Science, Bayelsa Medical University, Yenagoa, Bayelsa State, Nigeria
}

*Corresponding Author: Sylvester C. Izah, Department of Biological Science, Bayelsa Medical University, Yenagoa, Bayelsa State, Nigeria

\begin{abstract}
This study evaluated the effect of dichlorvos on selected metabolites, enzymes and electrolytes in some parts of Oryctolagus cuniculus (New Zealand Rabbits). A total of eighteen (18) healthy adult male New Zealand rabbits weighing 1.8 to $2.0 \mathrm{~kg}$ were obtained from a private rabbit farm in Mbiama, Rivers state of Nigeria and allowed to acclimatized to laboratory condition for 14 days. Then the rabbits were exposed to different concentration of the dichlorvos viz: $0.00 \mathrm{mg} / \mathrm{L}, 0.20 \mathrm{mg} / \mathrm{L}, 0.40 \mathrm{mg} / \mathrm{L}$ and $0.60 \mathrm{mg} / \mathrm{L}$ in a renewal bioassay technique for 14 days. Then after, the blood, brain and liver of the rabbits were obtained and analyzed for electrolyte (sodium and potassium), phosphatases (acid and alkaline) and metabolites (urea and creatinine) following standard protocols. Results of the phosphatases, metabolites and electrolytes showed significant variation $(p<0.05)$ across the concentrations which was not in dose depended pattern for most of the parameters. In addition, significant discrepancies $(p<0.05)$ exist between the liver and brain for the metabolites, blood and brain for the electrolytes for each of the concentration except for $0.60 \mathrm{mg} / \mathrm{L}$ for potassium. The fluctuation observed is an indication of the effect of stress associated with the dichlorvos. Hence, there is the need to produced pesticides that have minimal impact on non-target organisms especially vertebrates.
\end{abstract}

Keywords: Dichlorvos, Environmental Health, Oryctolagus cuniculus, Toxicity

\section{INTRODUCTION}

The use of pesticides in controlling pests has increased in many regions in Nigeria (Izah and Richard, 2020). Authors have defined pesticides as substances used to control, eradicate, mitigate and repel pests in agricultural field and home stead as pests (Izah and Richard, 2020, Inyang et al., 2016a,b). Since there are several pest including weeds, insects, etc, the choice of a particular pesticides depending on the intended pest to control or eradicate. As such, any substances that have potential to eradicates insects are known as insecticides. Insecticides are basically applied in household environment, stored products and agricultural field. Again, due to the toxicity of the chemical based insecticides its choice depends on where the intended pests to be controlled are domiciled.

In many areas in developing nation like Nigeria, dichlorvos also known as 2,2-dichlorovinyl dimethyl phosphate or 2, 3-dichlorovinyl dimethyl phosphate (Ojesanmi et al., 2017; Ogamba et al., 2015a; Ashade et al., 2011; Omoniyi et al., 2013; Yadav et al., 2012; Akinrotimi et al., 2018) is commonly used to control insects. Dichlorvos is active ingredients for the formulation of Otapiapia or Madararpiapia (Abdu et al., 2016), Nuvan, Sniper, Pia-pia (Hausa) (Chedi and Aliyu, 2010). Dichlorvos is an organophosphates group of pesticides that has broad spectrum insecticidal potentials. In the recent year it appears that the use of dichlorvos based insecticides in eradicating insects is as competitive as and mosquito coils and spray.

Dichlorvos has been reported to be toxic even in low concentration. Authors have reported it's toxic to fish life as well as other aquatic invertebrates. In human, dichlorvos can easily enter the body through inhalation (respiration), dermal (skin) and oral routes (ingestion) (Abdu et al., 2016; Chemicals Evaluation and Research Institute, 2007). Whatever the case, it's very toxic to the human 
body because prolong exposure or intake of dichlorvos could lead to a decline in plasma cholinesterase activity (Mishra and Poddar, 2014). In fishes, dichlorvos have been reported to induces behavioural and morphological alteration, histopathological, haematological, biochemical, enzymatic, electrolytes and developmental defects which could lead to death contingent upon the concentrations and exposure period (Izah and Richard, 2020).

Rabbits are vertebrates that survive environmental/ climatic condition with an annual rainfall of about $1000 \mathrm{~mm}$, and adequate cover within the feeding grounds. Several species of rabbit exist, but Oryctolagus cuniculus commonly called European rabbit, Japanese white rabbit, New Zealand rabbit and domestic rabbit have been used as experimental animals. Since the physiology of rabbit is closely related that of human, hence the need for its use in assessing the possible effect of dichlorvos on metabolites, electrolytes and enzymes in mammals. Basically, an aberration in the metabolites such as urea and creatinine of organisms may suggest possible dynfuctioning or stress condition of the kidney. While variation in electrolytes could adversely affect the proper function of some enzymatic, biochemical and physiological processes in animals including humans (Izah and Richard, 2020). Therefore, assessing the metabolites, enzymes and electrolytes in some parts of Oryctolagus cuniculus (New Zealand Rabbits) is very important, hence the need for this study.

\section{Materials AND Methods}

\subsection{Source of Experimental Animals and Acclimatization}

A total of eighteen (18) healthy adult male New Zealand rabbits weighing 1.8 to $2.0 \mathrm{~kg}$ were used for the investigation. The rabbits were obtained from a private rabbit farm in Mbiama, Rivers state of Nigeria. The rabbits were individually transported in a plastic basket to the laboratory where the experiment was conducted. In the laboratory, the rabbits were allowed to acclimatize to the rabbitory compartment. Each compartment housed one rabbit, and the acclimatization lasted for 14 days. During the period, the rabbits were fed with $200 \mathrm{~g}$ of synthetic growers' mash (pelletized) daily. $1.5 \mathrm{~L}$ of water was also placed in each compartment of the rabittory.

\subsection{General Bioassay Technique}

A range finding test was carried out to determine the actual concentration of the dichlorvos to be used for the main experiment, which lasted for 14 days. From the range finding test, four concentrations were made viz: $0.00 \mathrm{mg} / \mathrm{L}, 0.20 \mathrm{mg} / \mathrm{L}, 0.40 \mathrm{mg} / \mathrm{L}$ and $0.60 \mathrm{mg} / \mathrm{L}$ based on the formula previously described by Inyang et al. (2016a,b). Three rabbits were exposed to each concentration $(0.00 \mathrm{mg} / \mathrm{L}$, $0.20 \mathrm{mg} / \mathrm{L}, 0.40 \mathrm{mg} / \mathrm{L}$ and $0.60 \mathrm{mg} / \mathrm{L}$ ) of the dichlorvos.

Oral method was used to administer the dichlorvos to the experimental rabbits. The different concentration was mixed with $1.5 \mathrm{~L}$ of drinking water and the experimental rabbits were allowed to drink the water daily for 14 days. A 24 hours renewed bioassay technique was employed for this study. During the period the feed (synthetic growers' mash) and drinking water (containing the varying concentration of the toxicants) were renewed.

At the end of the experimental period, the blood of the exposed rabbit was collected before dissecting the rabbits to obtain the parts (liver and brain) for analysis of phosphatases, electrolytes and metabolites. $5 \mathrm{ml}$ of perchloric acid were added to each of the liver and brain samples and physiological saline and deionized water was used to preserve and stabilize the samples meant for electrolyte. All samples were centrifuged at the rate of 3000rpm for 15 minutes (Inyang et al., 2016a,b).

The electrolyte samples (sodium and potassium) were analyzed for the method described by Logarwarny et al. (2006) and APHA (1998). The phosphatases viz: acid phosphatase and Alkaline phosphatase were respectively analyzed following the methods previously described by Kind and King (1954) and Andersch and Szcypinski (1947). The metabolites viz: urea and creatinine were determined via Colorimetric methods of Weatherburn (1967) and Sehismeister et al. (1964) respectively.

\section{RESULTS AND DISCUSSION}

Table 1 shows the effects of dichlorvos on liver and brain metabolites of rabbit (Oryctolagus cuniculus). At $0.0,0.20,0.40$ and $0.60 \mathrm{mg} / \mathrm{L}$, the concentrations of urea in the liver were $2.17 \pm 0.09$ $\mathrm{g} / \mathrm{l}, 1.90 \pm 0.12 \mathrm{~g} / \mathrm{l}, 2.00 \pm 0.15 \mathrm{~g} / \mathrm{l}$ and $4.65 \pm 0.32 \mathrm{~g} / \mathrm{l}$, respectively. Statistically, there was significant discrepancies $(\mathrm{p}<0.05)$. Mean separation revealed that $0.60 \mathrm{mg} / \mathrm{l}$ concentration values were the 
sourced of the significant variation observed. In the brain, urea concentration was $3.74 \pm 0.04 \mathrm{~g} / \mathrm{l}$, $0.93 \pm 0.02 \mathrm{~g} / \mathrm{l}, 4.03 \pm 0.14 \mathrm{~g} / \mathrm{l}$ and $2.26 \pm 0.14 \mathrm{~g} / \mathrm{l}$ for $0.00,0.20,0.40$ and $0.60 \mathrm{mg} / \mathrm{L}$ concentrations. Significant variations $(\mathrm{p}<0.05)$ exist across the concentrations. Post hoc test showed no significant dissimilarity at 0.00 and $0.40 \mathrm{mg} / \mathrm{L}$ concentration. At various concentrations $(0.00,0.20,0.40$ and $0.60 \mathrm{mg} / \mathrm{L})$, there was significant variations $(\mathrm{p}<0.05)$ in the urea content in liver and brain. At 0.00 and $0.40 \mathrm{mg} / \mathrm{l}$, urea in brain were statistically higher than the level in the liver, and vice versa at 0.20 and $0.60 \mathrm{mg} / \mathrm{l}$ (Figure 1).

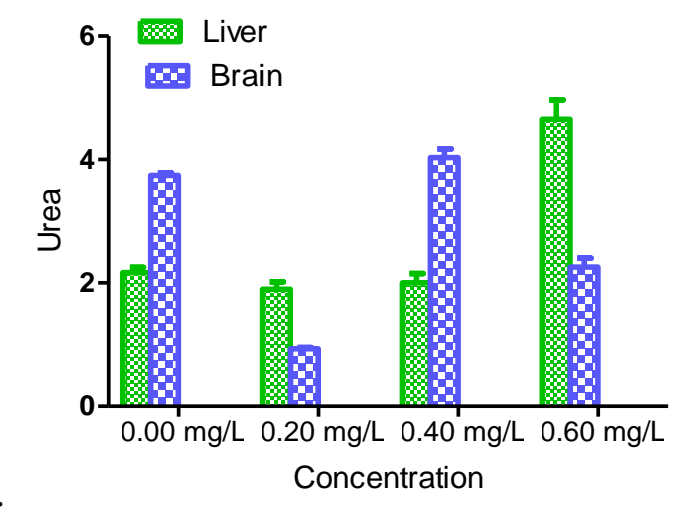

Figure1. Concentration of urea in liver and brain of rabbit (Oryctolagus cuniculus) exposed to sublethal concentration of dichlorvos

Table1. Effects of dichlorvos on liver and brain metabolites of rabbit (Oryctolagus cuniculus)

\begin{tabular}{|c|c|c|c|c|}
\hline \multirow{2}{*}{ Concentration, $\mathrm{mg} / \mathrm{L}$} & \multicolumn{2}{|c|}{ Liver } & \multicolumn{2}{c|}{ Brain } \\
\cline { 2 - 5 } & Urea, $\mathrm{g} / \mathrm{l}$ & Creatinine, $\mathrm{g} / \mathrm{l}$ & Urea, $\mathrm{g} / \mathrm{l}$ & Creatinine, $\mathrm{g} / \mathrm{l}$ \\
\hline 0.0 & $2.17 \pm 0.09 \mathrm{a}$ & $52.00 \pm 1.15 \mathrm{~b}$ & $3.74 \pm 0.04 \mathrm{c}$ & $1.75 \pm 0.14 \mathrm{c}$ \\
\hline 0.2 & $1.90 \pm 0.12 \mathrm{a}$ & $30.00 \pm 1.53 \mathrm{a}$ & $0.93 \pm 0.02 \mathrm{a}$ & $0.55 \pm 0.03 \mathrm{a}$ \\
\hline 0.4 & $2.00 \pm 0.15 \mathrm{a}$ & $32.33 \pm 1.20 \mathrm{a}$ & $4.03 \pm 0.14 \mathrm{c}$ & $2.64 \pm 0.03 \mathrm{~d}$ \\
\hline 0.6 & $4.65 \pm 0.32 \mathrm{~b}$ & $33.67 \pm 1.86 \mathrm{a}$ & $2.26 \pm 0.14 \mathrm{~b}$ & $1.32 \pm 0.08 \mathrm{~b}$ \\
\hline
\end{tabular}

Data is expressed as mean \pm standard error; different letters along the column is an indication of significant deviations according to Duncan statistics

At $0.0,0.20,0.40$ and $0.60 \mathrm{mg} / \mathrm{L}$, the concentrations of creatinine in the liver were $52.00 \pm 1.15 \mathrm{~g} / \mathrm{l}$, $30.00 \pm 1.53 \mathrm{~g} / \mathrm{l}, 32.33 \pm 1.20 \mathrm{~g} / \mathrm{l}$ and $33.67 \pm 1.86 \mathrm{~g} / \mathrm{l}$, respectively. Statistically, there was significant discrepancies $(\mathrm{p}<0.05)$. Mean separation revealed that $0.00 \mathrm{mg} / \mathrm{l}$ concentration values were the sourced of the discern significant variation. In the brain, creatinine concentration was $1.75 \pm 0.14 \mathrm{~g} / \mathrm{l}$, $0.55 \pm 0.03 \mathrm{~g} / \mathrm{l}, 2.64 \pm 0.03 \mathrm{~g} / \mathrm{l}$ and $1.32 \pm 0.08 \mathrm{~g} / \mathrm{l}$ for $0.00,0.20,0.40$ and $0.60 \mathrm{mg} / \mathrm{L}$ concentrations. Significant variations $(\mathrm{p}<0.05)$ exist across the various concentrations. At various concentrations $(0.00,0.20,0.40$ and $0.60 \mathrm{mg} / \mathrm{L})$, there was significant deviations $(\mathrm{p}<0.05)$ in the urea content in liver and brain. In all cases (concentration) creatinine in the liver were statistically higher compared to the level in the brain (Figure 2).

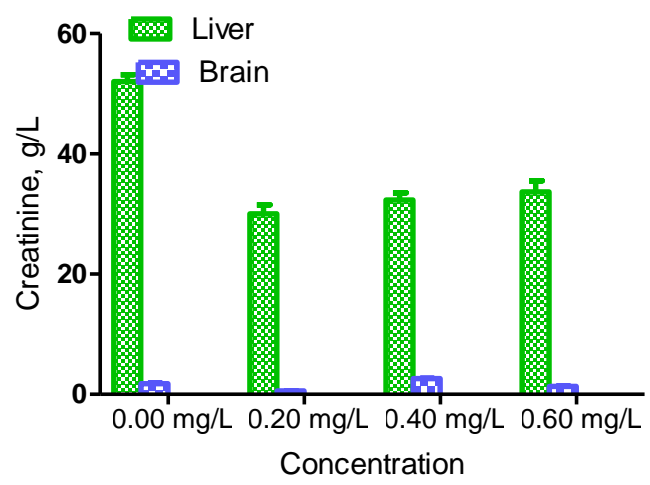

Figure2. Concentration of creatinine in liver and brain of rabbit (Oryctolagus cuniculus) exposed to sublethal concentration of dichlorvos 
Low creatinine content in the body especially the kidney may suggest its involvement in the contractile process in the muscle. Variations in creatinine values in the body especially at elevated value suggest kidney dyfunctioning (Amin and Hashem, 2012). Basically, an increase in the concentration of dichlorvos used in this study increased creatinine level in the rabbit (Oryctolagus cuniculus). Though slight fluctuation exists in some instances. This could be due to attempt made by the Oryctolagus cuniculus to metabolize the dichlorvos. Also a significant decline in creatinine value from the control is an indication of adverse effect of the toxicant on the experimental organisms. The significant fluctuation observed in this present study is an offshoot of stress induced by the dichlorvos especially in the muscle fibres of the probe organism (Inyang et al., 2016c).

An alteration in the urea content as the concentration increased may suggest kidney dyfunctioning. The increase is urea could be associated to the relationship between urea and increased protein catabolism or from more effective conversion of ammonia to urea due to elevation in the synthesis of enzyme involved in the production of urea in the experimental animals (Amin and Hashem, 2012).

Table 2 shows the effects of dichlorvos on blood and brain electrolytes of rabbit (Oryctolagus cuniculus). At $0.0,0.20,0.40$ and $0.60 \mathrm{mg} / \mathrm{L}$, the concentrations of sodium in the liver were $143.33 \pm 2.85 \mathrm{mmol} / \mathrm{L}, 151.00 \pm 28.88 \mathrm{mmol} / \mathrm{L}, 217.00 \pm 10.44 \mathrm{mmol} / \mathrm{L}$ and $144.67 \pm 23.56 \mathrm{mmol} / \mathrm{L}$, respectively. There were significant inconsistencies $(\mathrm{p}<0.05)$ across the concentrations. But post hoc statistics showed that $0.40 \mathrm{mg} / \mathrm{l}$ concentration values were the sourced of the statistical deviation observed. In the brain, sodium concentration was $14.00 \pm 2.31 \mathrm{mmol} / \mathrm{L}, 12.21 \pm 0.21 \mathrm{mmol} / \mathrm{L}$, $24.55 \pm 1.28 \mathrm{mmol} / \mathrm{L}$ and $11.20 \pm 0.15 \mathrm{mmol} / \mathrm{L}$ for $0.00,0.20,0.40$ and $0.60 \mathrm{mg} / \mathrm{L}$ of toxicant concentrations respectively. There were significant variations $(\mathrm{p}<0.05)$ across the concentrations and mean separation revealed that $0.60 \mathrm{mg} / \mathrm{l}$ concentration values were the sourced of the statistical aberration observed. At different concentrations $(0.00,0.20,0.40$ and $0.60 \mathrm{mg} / \mathrm{L})$, there was statistical deviations $(\mathrm{p}<0.05)$ in the sodium content in blood and brain. However, the sodium values were higher in the blood compare to the brain (Figure 3).

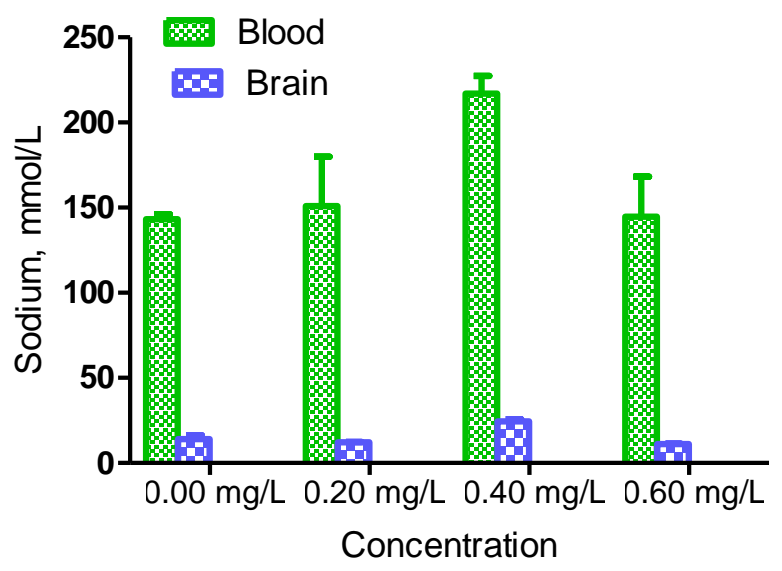

Figure3. Concentration of sodium in brain and blood of rabbit (Oryctolagus cuniculus) exposed to sublethal concentration of dichlorvos

Table2. Effects of dichlorvos on blood and brain electrolytes of rabbit (Oryctolagus cuniculus)

\begin{tabular}{|c|c|c|c|c|}
\hline \multirow{2}{*}{$\begin{array}{c}\text { Concentration, } \\
\mathrm{mg} / \mathrm{L}\end{array}$} & \multicolumn{2}{|c|}{ Blood } & \multicolumn{2}{c|}{ Brain } \\
\cline { 2 - 5 } & Sodium, mmol/L & Potassium, mmol/L & Sodium, mmol/L & Potassium, mmol/L \\
\hline 0.0 & $143.33 \pm 2.85 \mathrm{a}$ & $6.36 \pm 0.20 \mathrm{a}$ & $14.00 \pm 2.31 \mathrm{a}$ & $12.42 \pm 0.30 \mathrm{~b}$ \\
\hline 0.2 & $151.00 \pm 28.88 \mathrm{a}$ & $9.87 \pm 0.52 \mathrm{~b}$ & $12.21 \pm 0.21 \mathrm{a}$ & $12.55 \pm 0.73 \mathrm{~b}$ \\
\hline 0.4 & $217.00 \pm 10.44 \mathrm{~b}$ & $26.20 \pm 1.33 \mathrm{c}$ & $24.55 \pm 1.28 \mathrm{~b}$ & $14.71 \pm 1.41 \mathrm{~b}$ \\
\hline 0.6 & $144.67 \pm 23.56 \mathrm{a}$ & $7.73 \pm 0.41 \mathrm{ab}$ & $11.20 \pm 0.15 \mathrm{a}$ & $8.87 \pm 0.35 \mathrm{a}$ \\
\hline
\end{tabular}

Data is expressed as mean \pm standard error; different letters along the column is an indication of significant deviations according to Duncan statistics

At $0.0,0.20,0.40$ and $0.60 \mathrm{mg} / \mathrm{L}$, the concentrations of potassium in the liver were $6.36 \pm 0.20$ $\mathrm{mmol} / \mathrm{L}, 9.87 \pm 0.52 \mathrm{mmol} / \mathrm{L}, 26.20 \pm 1.33 \mathrm{mmol} / \mathrm{L}$ and $7.73 \pm 0.41 \mathrm{mmol} / \mathrm{L}$, respectively. There were significant inconsistencies $(\mathrm{p}<0.05)$ across the various concentrations. Potassium concentration was 
$12.42 \pm 0.30 \mathrm{mmol} / \mathrm{L}, 12.55 \pm 0.73 \mathrm{mmol} / \mathrm{L}, 14.71 \pm 1.41 \mathrm{mmol} / \mathrm{L}$ and $8.87 \pm 0.35 \mathrm{mmol} / \mathrm{L}$ for $0.00,0.20$, 0.40 and $0.60 \mathrm{mg} / \mathrm{L}$ of toxicant concentrations respectively. Significant variations $(\mathrm{p}<0.05)$ exist across the various concentrations of the toxicant except for $0.60 \mathrm{mg} / \mathrm{l}$ concentration. Apart from $0.6 \mathrm{mgl}$ concentrations, there was statistical deviations $(\mathrm{p}<0.05)$ in the potassium content in blood and brain across the various concentrations. Potassium content were higher in the brain compared to the blood except for $0.40 \mathrm{mg} / \mathrm{L}$ concentration (Figure 4).

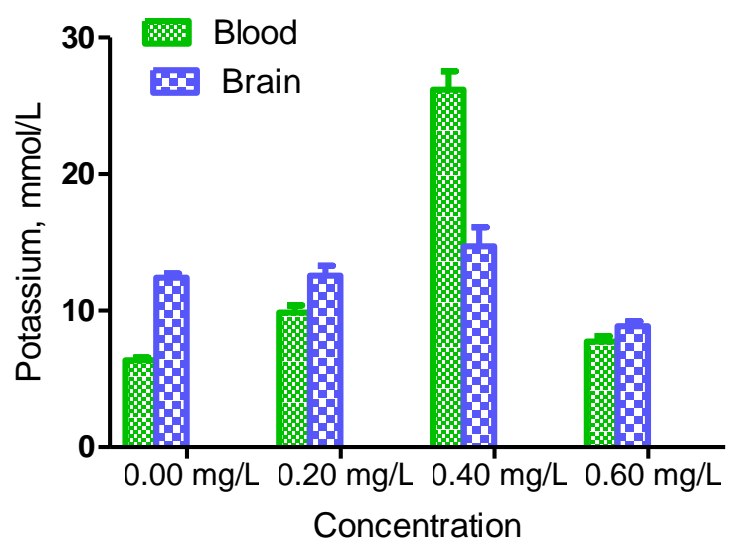

Figure4. Concentration of potassium in brain and blood of rabbit (Oryctolagus cuniculus) exposed to sublethal concentration of dichlorvos

The presence of the dichlorvos caused a sudden fluctuation in the electrolytes (potassium and sodium) in the blood and brain of Oryctolagus cuniculus. The abrupt change in the potassium and sodium is an indication of the effects of the toxicant on the test organisms (Ogamba et al., 2015a). in all cases, sodium content was higher compared to potassium, a trend that have been reported by Ogamba et al. (2015b), who studied Clarias gariepinus exposed to different concentrations of 2, 4Dichlorophenoxyacetic acid; Ogamba et al. (2015a) who studied the effects of dimethyl 2, 2 dichlorovinyl phosphate on Clarias gariepinus; and Inyang et al. (2016c) that studied the effect of fluazifop-p-butyl on Clarias gariepinus.

There was fluctuation in the electrolytes in both blood and brain of the experimental animal exposed to toxicants. This suggests that that the toxicant used in this study has effects on the electrolyte composition of the rabbits under study. Sodium is predominantly found in the body fluids, and potassium occurs majorly in the cells (Tacon, 1987). As such, the fluctuation in the electrolytes (potassium and sodium) concentration could be an indication of alteration of the rabbits blood and brain cells which could possibly lead to death, when exposed for long period.

The concentration of the different electrolytes (potassium and sodium) was significantly higher in liver apart from potassium at $0.60 \mathrm{mg} / \mathrm{L}$ concentration. Electrolytes facilitate the passage of fluid between and within cells through a process known as osmosis and also play a part in regulating the functioning of neuro-muscular, endocrine and excretory system of fishes (Inyang et al., 2016d). Basically, sodium and potassium are essential for the activity of many enzymes and have been implicated in the transport of ATP which participates in several metabolic processes (Erhunmwunse and Ainerua, 2014; Yelwa and Solomon, 2016). Specifically, potassium plays essential role in intracellular physiological functions such as nerve and muscle function, acid-base balance and osmotic pressure (Adamu and Francis, 2008; Inyang et al., 2016d), enzymatic transfer of phosphate from ATP to pyruvic acid and undoubtedly has a role in a number of basic cellular enzymatic functions (Muralidharan, 2014; Inyang et al., 2016d). A decline in the sodium concentration below the control could cause osmoregulatory problem. This is because osmoregulation and acid base balance play essential role in fishes (Muralidharan, 2014). According to Adamu and Francis (2008), a decline in sodium may cause alteration influx rate which may be due to ion loss due to dynfunctioning of the osmoregulatory processes (Muralidharan, 2014).

Table 3 shows the effects of dichlorvos on liver enzymes (Alkaline and acid phosphatases) of rabbit (Oryctolagus cuniculus). At $0.0,0.20,0.40$ and $0.60 \mathrm{mg} / \mathrm{L}$, the concentrations of alkaline phosphatase were $55.00 \pm 2.65 \mu / 1,43.33 \pm 2.85 \mu / 1,36.00 \pm 1.73 \mu / 1$ and $845.67 \pm 27.81 \mu / 1$, respectively. Apart from 
the $0.60 \mathrm{mg} / \mathrm{L}$ concentration of toxicant, the values of alkaline phosphatase showed no significant variation $(\mathrm{p}<0.05)$ as the concentration of the toxicant increased. For the acid phosphatases, the concentration was $1851.33 \pm 30.03 \mu / 1,1901.33 \pm 63.04 \mu / 1,1327.67 \pm 39.73 \mu / 1$ and $1431.33 \pm 30.83 \mu / 1$ for $0.0,0.20,0.40$ and $0.60 \mathrm{mg} / \mathrm{L}$ concentration of the toxicant. Statistically, significant deviation exists. But mean separation revealed that there is no significant deviation between 0.00 and $0.20 \mathrm{mg} / \mathrm{L}$, and between 0.40 and $0.60 \mathrm{mg} / \mathrm{L}$ concentration of the toxicants. Fluctuations exist in the values of the enzymes as concentration of the toxicants increased. The differences observed especially at higher concentration is an indication of cellular toxicity of dichlorvos. Basically, an inhibitions of enzymes such as alkaline and acid phosphatases could contribute significantly to the inhibition of intermediary metabolic processes (Begum, 2004). An elevation in this enzymes may suggest liver damage (Inyang et al., 2016a). Alkaline phosphatase activity is a reflection of changes in endoplasmic reticulum mass. According to Anderson et al. (2002), a decrease in alkaline phosphatase may lead to a decline in the rate of synthesis caused by lowered metabolic demands.

Acid phosphatase concentration in this study was on the decline trend, which as an indication of the effect of toxicant on the experimental animals. The decline in values may be connected to the leakage of the enzyme into extracellular compartments and/ or tissue damage (Ambali et al., 2007) This could hinder the activities of acid phosphatase which Jawale (2016) reported that it's a hydrolytic lysosome enzyme that hydrolysis of foreign material. Therefore, the alteration in acid and alkaline phosphatases suggest the stress condition of the probe organism due to the presence of toxicant.

Table3. Effects of dichlorvos on liver enzymes of rabbit (Oryctolagus cuniculus)

\begin{tabular}{|c|c|c|}
\hline Concentration, $\mathrm{mg} / \mathrm{L}$ & Alkaline phosphatase, $\mu / \mathrm{l}$ & Acid phosphatase, $\mu / 1$ \\
\hline 0.0 & $55.00 \pm 2.65 \mathrm{a}$ & $1851.33 \pm 30.03 \mathrm{~b}$ \\
\hline 0.2 & $43.33 \pm 2.85 \mathrm{a}$ & $1901.33 \pm 63.04 \mathrm{~b}$ \\
\hline 0.4 & $36.00 \pm 1.73 \mathrm{a}$ & $1327.67 \pm 39.73 \mathrm{a}$ \\
\hline 0.6 & $845.67 \pm 27.81 \mathrm{~b}$ & $1431.33 \pm 30.83 \mathrm{a}$ \\
\hline
\end{tabular}

Data is expressed as mean \pm standard error; different letters along the column is an indication of significant deviations according to Duncan statistics

\section{CONCLuSion}

This study investigated the effect of dichlorvos on selected metabolites, enzymes and electrolytes in some parts of Oryctolagus cuniculus (New Zealand Rabbits), a mammal. The study found electrolyte (sodium and potassium), phosphatases (acid and alkaline) and metabolites (urea and creatinine) across the various concentration of the toxicants. In addition, significant inconsistencies $(p<0.05)$ exist between the liver and brain for the metabolites, blood and brain for the electrolytes. The significant variations across the various concentrations suggest the effect of stress accrued to the toxicant. Hence, there is the need for research to focus on the production of pesticides with minimal toxic effect on non-target organisms on their environment.

\section{REFERENCES}

[1] Abdu, I. T., Adamu, L. H., Modibbo, M. H., and Yusuf, A. A. (2016). Effect of dichlorvos on histoarchitecture of the cerebral blood vessels in adult wistar rats. T,HE Journal of Neurobehavioral Sciences, 3(1), 7 - 12 .

[2] Adamu, M. K., and Francis, O. A. (2008). Concentration of Electrolyte Reserves of the Juvenile African Catfish Clarias gariepinus (Burchell, 1822) Exposed to Sublethal Concentrations of Portland Cement Powder in Solution. Pakistan Journal of Science and Industrial Research, 51(6), 323-328.

[3] Akinrotimi O. A., Wilfred, E. P. C., and Ukwe, O. I. K. (2018). Effects of 2, 2-Dichlorovinyl Dimethyl Phosphate (DDVP) on leukocyte profiles in juveniles and adult sizes of Tilapia guineensis. MOJ Immunol. 6(5), 173-176.

[4] Andersch, M. A., and Szcypinski, A. J. (1947). A colorimetric method for determination of acid phosphatase from serum. Amer. J. Pathd. 17, 571-574.

[5] Ambali, S., Akanbi, D., Igbokwe, N., Sittu, M, Kawu, M., and Ayo, J. (2007). Evaluation of sub-chronic chloropyrifos poisoning on haematological and serum biochemical changes in mice and protective effect of vitamin C. Journal of Tropical Science, 32(20), 11-20.

[6] Amin, K. A., and Hashem, K. S. (2012). Deltamethrin-induced oxidative stress and biochemical changes in tissues and blood of catfish (Clarias gariepinus): antioxidant defense and role of alpha-tocopherol. BMC Veterinary Research, 2012, 8:45.http://www.biomedcentral.com/1746-6148/8/45. 
[7] Anderson, T., Forlin, L., Hardig, J., and Larsson A. (2002). A physiological disturbances in fish living in coastal water polluted with bleached Kraft pulp mill effluents. Canadian Journal of Fish and Aquatic Science, 45, 1525-1536.

[8] APHA (American Public Health Association) (2008). Standard Methods for the Examination of Water and Wastewater, 23rd ed; American Public Health Association: Washington, DC, USA.

[9] Ashade, O. O., Ashiru, A. W., and Obiri, C. M. (2011). The comparative study of the toxic effects of $2-3$ diclorovinyl dimethyl phosphate (2,3 dichlorovinyl dimethyl phosphate) and chlorpyrifos on the behaviour and haematology of african-(Clarias gariepinus). International Journal of Science \& Society Yabatech, $1(1), 38-47$.

[10] Begum, G. (2004). Carbofuran insecticide induced biochemical alterations in liver and muscle tissues of fish Clarias batrachus (Linn) and recovery response. Aquatic Toxicology, 66(1), 83-92.

[11] Chedi, B. A. Z., and Aliyu, M. (2010). Effect and management of acute dichlorvos poisoning in Wistar rats. Bayero Journal of Pure and Applied Sciences, 3(2), 1 - 3.

[12] Chemicals Evaluation \& Research Institute (CERI), Japan (2007). Hazard assessment report on Dimethyl 2, 2-dichlorovinyl phosphate. CAS no. 62-73-7.

[13] Erhunmwunse, N. O., and Ainerua, M. O. (2014). Effect of Glyphosate Herbicide (360g/l) On Some Biochemical Electrolytes of Exposed Africa Catfish. IOSR Journal of Environmental Science, Toxicology and Food Technology, 8(1), 27 - 29.

[14] nyang, I. R., Thomas, S., and Izah, S. C. (2016a). Evaluation of Activities of Transferases and Phosphatase in Plasma and Organs of Clarias gariepinus Exposed to Fluazifop-p-Butyl. Journal of Environmental Treatment Techniques, 4(3), 94-97

[15] Inyang, I. R., Thomas, S., and Izah, S. C. (2016b). Activities of electrolytes in kidney and liver of Clarias gariepinus exposed to fluazifop-p-butyl. Journal of Biotechnology Research, 2(9), 68-72.

[16] Inyang, I. R., Akio, K., \& Izah, S. C. (2016c). Effect of dimethoate on some selected metabolites in the brain, liver and muscle of Clarias lazera. Sky Journal of Biochemistry Research, 5(4), 63-68

[17] Inyang, I. R., Okon, N. C., and Izah, S. C. (2016d). Effect of glyphosate on some enzymes and electrolytes in Heterobranchus bidosalis (a common African catfish). Biotechnological Research, 2(4), 161-165.

[18] Izah, S.C., and Richard, G. (2020). Toxicity of Dichlorvos (2, 2- Dichlorovinyl Dimethyl Phosphate) on Fish Life. In: Recent Advances in Biological Research Vol. 6. Pp 70 - 78.

[19] Jawale, C. A. (2016). Consequence of organophosphate dimethoate pesticide on acid phosphatase activity in gills of freshwater fish, Catla catla. Flora and Fauna, 22(1), 89-92.

[20] Kind, P. R., and King, E. G. (1954). Estimation of plasma phosphate by determination of hydrolyzed phenol with amino antpyrine. Journal of Clinical Pathology 7, 56-63.

[21] Logarwarny, S., Radha, G., Sbhheshedi, S., and Longankumar, K. (2006). Alteration in the levels of ions in blood and liver of fresh water fish cyprinus Carpio exposed to dimethorate. Environmental Monitoring Assessment, 133, 1-3

[22] Mishra, A., and Poddar, A. N. (2014). Acute toxicity and behavioral response of the food fish Channa punctatus (bloch)to an insecticide dichlorvos. Jr. of Industrial Pollution Control, 30(2), 219-222.

[23] Muralidharan, L. (2014). Impact of Fenthion on Ionic Regulation in the Blood of Freshwater Fish, Cyprinus carpio (Linn). IOSR Journal of Environmental Science, Toxicology and Food Technology, 8(1), 63-70.

[24] Ogamba, E. N., Izah, S. C. and Numofegha, K. (2015a). Effects of dimethyl 2,2-dichlorovinyl phosphate on the sodium, potassium and calcium content in the kidney and liver of Clarias gariepinus. Research Journal of Pharmacology and Toxicology, 1(1), 27-30.

[25] Ogamba, E. N., Izah, S. C., and Nabebe, G. (2015b). Effects of 2, 4-Dichlorophenoxyacetic acid in the electrolytes of blood, liver and muscles of Clarias gariepinus. Nigeria Journal of Agriculture Food and Environment, 11(4), 23- 27.

[26] Ojesanmi, A. S., Richard, G., and Izah, S. C. (2017). Mortality Rate of Clarias gariepinus Fingerlings Exposed to 2, 3- dichlorovinyl dimethyl Phosphate. Journal of Applied Life Sciences International, 13(1), $1-6$

[27] Omoniyi, I. T., Adeogun, K. L., and Obasa, S. O. (2013). Lethal effects of 2,2 - dichlorovinyl dimethyl phosphate (DDVP) on fingerling and juvenile Clarias gariepinus burchell, 1822. Croatial Journal of Fisheries 71, 19 - 24

[28] Schimeister, J., Willmann, H., and Kiefer, H. (1964). Standard methods for evaluation of metabolites in organisms. Harpes and Row Publishers. 
Effect of Dichlorvos on Selected Metabolites, Enzymes and Electrolytes in Some Parts of Oryctolagus Cuniculus (New Zealand Rabbits)

[29] Tacon, A. G. J. (1987). The nutrition and feeding of farmed fish and shrimp - a training manual. 1. The essential nutrients. Food and agriculture organization of the united nations Brasilia, Brazil. http://www.fao.org/docrep/field/003/ab470e/ ab470e06.htm. Accessed June 28th, 2015.

[30] Weathesburn, M. W. (1967). Analytical chemistry. Evans publishers.

[31] Yadav, P., Jadhav, S. E., Kumar, V., Kaul, K. K., Pant, S. E., and Flora, S. J. S. (2012). Protective efficacy of 2-PAMCl, atropine and curcumin against dichlorvos induced toxicity in rats. Interdiscip Toxicol. 5(1), 1-8.

[32] Yelwa, S. T., and Solomon, R. J. (2016). Effect of Weight and Length on Electrolyte of Catfish (Clarias gariepinus). International Journal of Farming and Allied Sciences, 5 (4), 295-307.

Citation: Sylvester C. Izah, et al., " Effect of Dichlorvos on Selected Metabolites, Enzymes and Electrolytes in Some Parts of Oryctolagus Cuniculus (New Zealand Rabbits).", International Journal of Research in Environmental Science (IJRES), vol. 6, no. 1, pp. 19-26, 2020. Available: DOI: http://dx.doi.org/10.20431/ 2454-9444.0601003

Copyright:(C) 2020 Authors. This is an open-access article distributed under the terms of the Creative Commons Attribution License, which permits unrestricted use, distribution, and reproduction in any medium, provided the original author and source are credited. 